\title{
The Stra.Tech.Man Scorecard
}

\author{
Charis Vlados ${ }^{1,2}$ \\ ${ }^{1}$ Department of Economics, Democritus University of Thrace, Panepistimioupoli, Komotini, Greece \\ ${ }^{2}$ School of Business, University of Nicosia, 46 Makedonitissas Avenue, CY-2417, Nicosia, Cyprus \\ Correspondence: Charis Vlados, Department of Economics, Democritus University of Thrace, Panepistimioupoli, \\ 69100, Komotini, Greece.
}

Received: January 3, 2021

Accepted: February 19, 2021

Online Published: February 23, 2021

doi:10.5430/ijba.v12n2p36

URL: https://doi.org/10.5430/ijba.v12n2p36

\begin{abstract}
This article presents the "Stra.Tech.Man approach" (strategy-technology-management synthesis) as the basis for creating a "Stra.Tech.Man Scorecard," which can be used for the strategic audit of every socio-economic organization. After reviewing the literature on strategic control and strategic audit, the study proceeds with a critical appraisal of Kaplan and Norton's balanced scorecard model and presents the theoretical foundations of the Stra.Tech.Man approach. It composes a first conceptual outline of the Stra.Tech.Man Scorecard, which can function as an integrated monitoring tool, exploring and describing the evolution of "physiologies" of the studied socio-economic organizations (firms). It concludes that the formal balanced scorecard approach: (a) has been applied mainly to larger and more sophisticated organizations, (b) does not offer a compound understanding of the central dimensions of strategy, technology, and management that can be linked in an integrated way to the financial results, (c) leaves relatively unspecified many critical aspects of a firm's choices, especially in strategy articulation, technology selection, and management implementation, (d) does not create complete profiles for the firms' evolutionary physiologies. In contrast, the Stra.Tech.Man Scorecard: (i) does not have as a prerequisite any pre-existing systematic performance measurement framework in the organization and, therefore, it is not limited by any firm size, type, or physiology, (ii) it links in an evolutionary way the "core" qualitative dimensions of strategy, technology and management (Stra.Tech.Man audit) with the quantitative financial results of the organization, (iii) it can and has been used as an integrated analysis instrument by taking into account more adequately the evolutionary dimensions of the meso-environment of organizations besides the micro-level of analysis which the balanced scorecard is primarily associated.
\end{abstract}

Keywords: balanced scorecard, Stra.Tech.Man approach, Stra.Tech.Man scorecard, strategic control, strategic audit, Stra.Tech.Man audit

\section{Introduction}

New methods and approaches continuously appear recently to create strategic control frameworks based on performance measurement systems (Beuren and Dal Vesco, 2021; Cardoni et al., 2020; Katamei et al., 2015; Mahadeen et al., 2016). Like Kaplan and Norton's well-known balanced scorecard model, it seems that such frameworks do not effectively address dimensions that the emerging field of strategic audit considers as fundamental. Strategic audit raises broader questions of qualitative and evolutive nature that specialized (and focused primarily for high-performing companies) performance measurement systems bypass. The reason is that they do not aim at businesses that cannot build systematic quantitative control mechanisms due to physiological limits (Meyer and Davis, 2003; Reeves et al., 2016; Vlados, 2019a). By identifying this gap in international practice and scorecard applications (Sedysheva, 2012; Smith and Loonam, 2016), we attempt in this article to place the "Stra.Tech.Man approach" (strategy-technology-management synthesis) within a scorecard framework. We aim to counter-propose a new strategic audit framework geared towards the parallel measurement of financial efficiency.

Following related analyses offered by Jaakkola (2020) and Gilson and Goldberg (2015), this conceptual paper aims to build a new model - a more flexible, simplest, more operationally accessible, and integrated framework upon the balanced scorecard method. In this research design, the suggested model appears sufficiently apt to describe and predict relationships between constructs and results. These constructs correspond to naming novel connections (the Stra.Tech.Man approach in this case), developing repositioned theoretical propositions (a scorecard not only for 
high-performing and sophisticated controlled firms), and explaining why a sequence of events leads to an outcome (a "Stra.Tech.Man Scorecard" questionnaire synthesizes all the analytical elements of the examined organization). To this end, section two reviews critical historical points in the literature of strategic control and strategic audit. In section three, we present a critical appraisal of the standard balanced scorecard model. In section four, we focus on the main points of the Stra.Tech.Man approach. In section five, we attempt a synthesis, in what we call a Stra.Tech.Man Scorecard. In the concluding section, we discuss the limitations and prospects for research and implementation of this novel theoretical framework.

\section{Strategic Control and Strategic Audit}

Starting in the 1970s, management theorists and large corporations' managers noticed that even the best possible planning processes could not deal effectively with the dramatic internal and external changes occurring between the initially conceived and the implemented strategic plan. A common observation was that inaccurate planning assumptions and frequent environmental changes invalidated strategic plans before their final execution (Ansoff $e t$ al., 1973; Schendel and Hatten, 1972). According to Taylor (1973), referring to the back-then conception of this process, no plan can survive contact with reality. The earlier strategic management theory's inability to deal sufficiently effectively with change and cope with unsatisfactory results led theorists to suggest applying traditional management control instead of strategic planning or strategic implementation solely (Goold and Quinn, 1990). Controlling was long before a fundamental management activity, defined as verifying whether everything occurs in conformity with the adopted plan (Fayol, 1949). Therefore, this relationship between the controlling process and planning was perceived as fundamental in the relevant literature (Robbins et al., 2020).

Strategic control, traditionally, refers to the control process of creating and executing strategic plans. It is a specialized form of control and differs from other such activities, such as operations management control, focusing on handling uncertainty, strategic risk and change (Beer, 1980, 1972). Strategic control focuses on achieving future goals rather than assessing past performance since it aims to assess whether the organization's performance so far is as expected and to inspect the conditions for future strategic effectiveness (Seifzadeh and Rowe, 2019). In other words, also according to the views of Horovitz (1979) and Ruefli and Sarrazin (1981), who are early theorists of strategic control, this method aims to recognize necessary corrections to the current and desirable course of the business. Overall, a framework of management control can consist of four parts: (a) setting standards, (b) measuring performance, (c) comparing the performance with the standards, and (d) taking proper action. Focusing on the various parts of this process is a usual practice in the early literature of the subject (Koontz, 1958), while others divide one or more parts to offer additional detail to the controlling scheme (Griffin, 2012). After earlier efforts to link strategic planning with fundamental management control practices, strategic control became a final strategic management phase (Lorange and Morton, 1974; Newman, 1975; Schendel, 1979).

If "strategic control" is the last phase in the strategic management process, "strategic audit" refers to a more general practice in which overall supervision of the organization is realized, usually considering certain general principles governing it (or should govern it). The strategic audit concept first appeared in the late 1980s and is still an emerging rather than established strategic management theory (Note 1). Table 1 presents four central concepts and methods followed by strategic audit theorists.

Table 1. Strategic audit concepts and methodologies over time

\begin{tabular}{lll}
\hline Author & Main concept & Strategic audit methodology \\
\hline $\begin{array}{l}\text { Donaldson } \\
(1995)\end{array}$ & $\begin{array}{l}\text { There is constant pressure on } \\
\text { boards of directors, and } \\
\text { strategic audit is a way to } \\
\text { review strategy without } \\
\text { invading management's } \\
\text { territory. }\end{array}$ & $\begin{array}{l}\text { Outside directors should constitute a strategic audit } \\
\text { committee that meets every three years to evaluate } \\
\text { strategy using objective financial measurements with } \\
\text { which both the directors and the CEO are thoroughly } \\
\text { comfortable. }\end{array}$ \\
\hline $\begin{array}{l}\text { Hunger and } \\
\text { Wheelen }\end{array}$ & $\begin{array}{l}\text { The strategic audit is a } \\
\text { diagnostic tool to find problem } \\
\text { areas and highlight strengths } \\
\text { and weaknesses. Each question } \\
\text { in a particular area of the } \\
\text { strategic audit can lead to }\end{array}$ & $\begin{array}{l}\text { An eight-step strategic decision-making process: 1) } \\
\text { Evaluate current performance results; 2) Review } \\
\text { corporate governance; 3) Scan the external environment; } \\
\text { 4) Scan the internal corporate environment; 5) Analyze } \\
\text { strategic factors; 6) Generate, evaluate, and select the } \\
\text { best alternative strategy; 7) Implement selected }\end{array}$ \\
\hline
\end{tabular}




\begin{tabular}{|c|c|c|}
\hline & further sub-questions. & strategies; 8) Evaluate implemented strategies. \\
\hline $\begin{array}{l}\text { Gordon } \\
\text { (1997) }\end{array}$ & $\begin{array}{l}\text { Strategic audits have } \\
\text { unpredictable results. This } \\
\text { process's most significant } \\
\text { outcome may not be a } \\
\text { good-looking strategic report, } \\
\text { but the participants' } \\
\text { commitment to shape and } \\
\text { reshape, learn, and correct the } \\
\text { organization's moves. }\end{array}$ & $\begin{array}{l}\text { Ten strategic audit questions function as "a springboard } \\
\text { to transcend linear planning, hard-vs-soft criteria, and } \\
\text { the scientific method": In what business are we? What } \\
\text { forces are shaping competition? Where is a competitive } \\
\text { advantage? What about functional area indicators? How } \\
\text { will we best compete in the future? What is our current } \\
\text { strategy? Is there money to be made? What is our } \\
\text { distinctive competence? What of priorities, timing, and } \\
\text { resources? What provisions exist for implementation? }\end{array}$ \\
\hline $\begin{array}{l}\text { Grundy } \\
\text { (2008) }\end{array}$ & $\begin{array}{l}\text { The concept of a strategy audit } \\
\text { is not unlike having a private } \\
\text { healthcare check-up. A strategy } \\
\text { audit can be the systematic, } \\
\text { structured, and comprehensive } \\
\text { and detailed review of the } \\
\text { strategy and strategic processes } \\
\text { to find weaknesses, blind spots, } \\
\text { and areas where potentially far } \\
\text { more value can be added. }\end{array}$ & $\begin{array}{l}\text { Strategy audit is conducted at various levels, such as } \\
\text { corporate strategy, business strategy, financial strategy, } \\
\text { cross-functional strategy, supporting processes/skills. } \\
\text { Multiple semi-quantitatively scored questions can be the } \\
\text { primary method (for example, between one and five). } \\
\text { The overall scores can be compiled for each section of } \\
\text { the audit and then either weighted or left unweighted, } \\
\text { then added to give a final total score. The results then } \\
\text { can be challenged by asking questions like "why do we } \\
\text { say this" or "what evidence do we have to support this." }\end{array}$ \\
\hline
\end{tabular}

Therefore, we see various strategic audit methodologies, which have a common feature that they understand this critical process within the organization as a necessary check-up or diagnosis from time to time. From this literature review, we derive that the strategic audit approaches seem not to include comprehensive financial data measurement. In contrast, the approaches to strategic control do not consider from an integrated perspective qualitative and self-evaluation dimensions that are "ubiquitous" in the strategic audit.

One approach that seems to cover these two distinct but overlapping theoretical fields is performance measurement. According to Chapman (2005), implementing efficient strategic performance measurement systems requires adding sophistication to the choice and analysis of strategic performance measures and targets. This means emphasizing quantitative and qualitative analysis techniques for selecting the properly aligned measures (Andrikopoulos et al., 2013). Neely (2005) offers a thorough review of the performance measurement literature since its inception to date (Argyris, 1952; Chandler, 1977; Drucker, 1954; Ridgway, 1956), referring to the need expressed by early theorists to have a "balanced" group of measures within the organizations. As Neely continues, various measurement frameworks appeared from time to time, with the most popular being that of Kaplan and Norton (1992), for which he argues that new research problems are coming to the surface, mostly concerning the need to build dynamic rather than static measurement systems, ensuring a focus on measuring the performance of the organization altogether and not in parts. In this context, we present and critically evaluate Kaplan and Norton's original balanced scorecard model in the next section, discussing its interpretive value and fundamental virtues.

\section{Critical Evaluation of the Balanced Scorecard Framework (BSC)}

The balanced scorecard is a tool to approximate the strategic management performance that managers can use to control their companies' actions. This section first presents the balanced scorecard model's main conceptual components over time and then critically analyzes substantial relevant criticisms.

\subsection{The Foundation and Development of Kaplan and Norton's Balanced Scorecard}

The balanced scorecard focuses on the company's strategic framework, considering and combining specific information to inspect a mix of financial and non-financial components and data. The balanced scorecard examines four areas that contribute to the corporation's performance: financial perspective, customer perspective, internal business perspective, and innovation and learning perspective (Figure 1). 


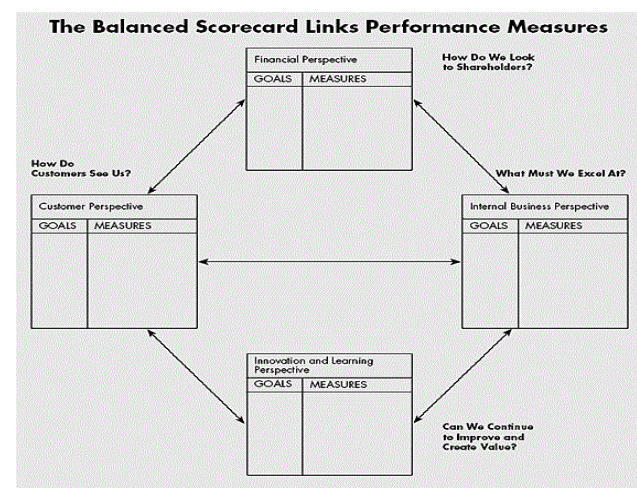

Figure 1. The first balanced scorecard by Kaplan and Norton (1992)

The balanced scorecard's structure and method offer answers to the four related questions of "How do customers see us?" (Customer perspective), "What must we excel at?" (Internal perspective), "Can we continue to improve and create value?" (Innovation and learning perspective), and "How do we look to shareholders?" (Financial perspective). All this information comes from and must be calibrated towards pulling the company's people towards the overall corporate vision and mission.

More specifically, Kaplan and Norton's balanced scorecard appeared, as the authors say, after years of research in twelve companies at the leading edge of performance measurement (Kaplan \& Norton, 1992). Using the (now-classic) airplane cockpit metaphor, Kaplan and Norton suggested that the balanced scorecard is what the buttons and indicators are for a pilot, who always needs to fly the plane with detailed information that summarizes both the current and predicted environment. This is how the authors argued that we need to understand an organization's management nowadays, observing its performance in various and simultaneous aspects and operations (Kaplan \& Norton, 1992). According to Kaplan and Norton, the balanced scorecard aims to confine information overload as much as possible, limiting the number of strategic control measures used because it is common in an enterprise to have too many relevant measures. Rightly stated (Kaplan \& Norton, 1996), the balanced scorecard translates the company's vision and mission to a comprehensive and necessary set of performance indicators.

Following this foundation period, Kaplan and Norton (2001) identified that companies that used the balanced scorecard successfully belong to a category of strategy-focused organizations, which must and can articulate "strategic maps" that include all the steps these organizations take to create value (Kaplan \& Norton, 2004). A set of strategic objectives plotted on a strategic linkage model (or strategy map) becomes the second generation of balanced scorecards progressively (Note 2). With this transpositioned and enriched approach, distinct strategic objectives among the four perspectives come together to form an overall presentation of specific measures and targets that correspond altogether to partial initiatives and budgets (Figure 2).

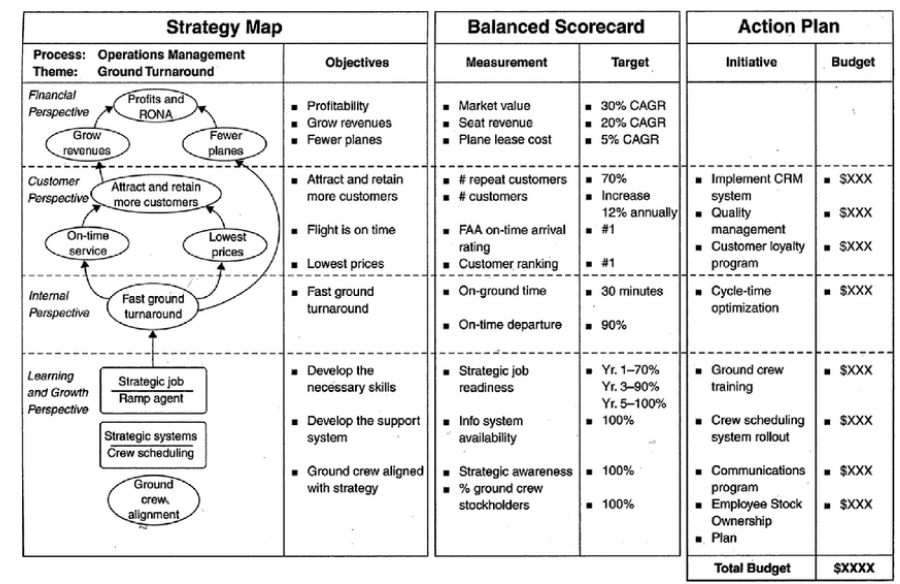

Figure 2. Strategy map, balanced scorecard and action plan (Kaplan \& Norton, 2004, p. 53) 
In this second generation, Kaplan and Norton drive the early dashboard framework to a simultaneous generalization (strategy maps) and specification (action plans). Kaplan and Norton (2004) suggest these action plans are not standalone projects but bundles of investment, which will add to the performance when aligned around the business case-specific strategic themes. Afterward, Kaplan and Norton (2006) suggested that these strategic maps can help align the various organizational units, emphasizing strategy implementation at the organization's operational processes.

Trying to augment their arguments and the balanced scorecard's practical application, the authors identified in the "Execution premium" (Kaplan \& Norton, 2008) a need for a new organizational function, called the office of strategy management (OSM). This "office" is an internal business system to help coordinate and execute the strategy, sometimes referred to as an approach that led to the third generation of balanced scorecards (Figure 3).

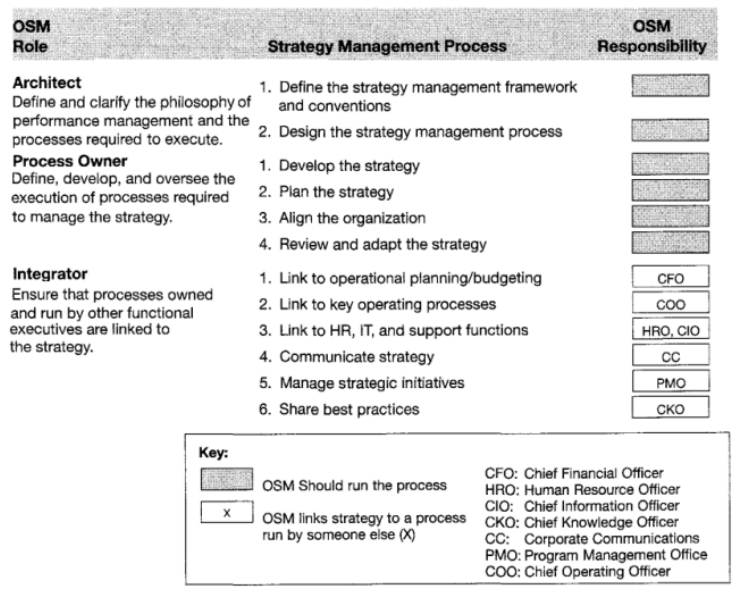

Figure 3. Roles and responsibilities of the office of strategy and management (OSM)

Source: An adjustment was made based on Kaplan and Norton's $(2008$, pp. 19, 287) original

OSM integrates the balanced scorecard with management tools in a closed-loop system of six stages to offer a comprehensive management system that aligns all standalone subsystems (functions and business units). According to Kaplan and Norton (2008), the OSM - mostly in high-performing companies—synchronizes the various planning and control processes that operate at different frequencies. Offering the timeframe, Kaplan and Norton (2008, p. 19) suggest that "dashboards and operational control meetings operate daily and weekly, information on strategic measures and initiatives is collected monthly to inform the strategy reviews meetings, and the organizational scan of the external environment an analytic studies are done quarterly or annually for strategy testing and adapting meetings. All these cycles must be compatible with and integrated with one another."

Overall, the balanced scorecard frameworks managed to offer a more in-depth performance measurement theory and practice. Instead of only examining costs and profits, which may echo short-term performance solely, the balanced scorecard complements this area with long-term performance indicators (the other three perspectives). Summarizing this brief presentation of Kaplan and Norton's evolving balanced scorecard framework, the authors have presented their scorecard as a strategic control system that has the benefit of combining financial and non-financial indicators with internal and external influences affecting corporate strategy. It connects long-term strategic goals with short-term annual budgets, aligns managers' and employees' personal goals with the organization's strategic goals while defining, monitoring, and communicating individual and collective performance.

\subsection{Criticisms, Extensions and Reviews of Kaplan and Norton's Balanced Scorecard Framework}

The "Tableau de Bord" - more than 60 years old - is a similar framework to the balanced scorecard used for decades by French managers to control performance based on critical organizational parameters (Madsen and Stenheim, 2015). The tableau de bord was introduced as a tool for the top management to offer a quick and comprehensive view of a firm's operations and the environment by evolving later into a diagnostic tool to help managers in the strategy implementation (Epstein and Manzoni, 1997). According to Bourguignon et al. (2004), the tableau de bord is more useful than the balanced scorecard to the extent that the French business culture promotes significant 
interaction between hierarchical levels and shared responsibility among managers. In this context, Epstein et al. (2010, p. 88) postulate that the balanced scorecard presumes a top-down and mechanistic "deployment of strategy, objectives, and measures in the organization, ignoring the fact that strategy is often a process of incremental and collective construction." However, to this end, we cannot deny that Kaplan and Norton are undoubtedly those who further diffused and popularized the need to create such enterprise-wide strategic control instruments.

Moreover, the second generation has received criticisms to the extent that strategic maps have a linear and static nature as they assume a logical sequence of relationships between performance metrics that can lead organizations to be too occupied with performance measurement instead of performance management (Brignall, 2002; Norreklit, 2000). To this end, Kaplan and Norton's balanced scorecard approach has at times been the subject of criticism. The most heated is by Voelpel et al. (2006), for which Kaplan and Norton (2006) provided answers to each of the criticism's specific points. While we mostly agree with Kaplan and Norton's arguments in this debate, we aim to collect the highlights of all the criticisms presented at the end of this sub-section and focus on the points that we think the critiques are valid. The eventual goal is to emphasize specific criticisms that can lead us to enrich the debate and offer a new theoretical perspective:

- Critique by Voelpel et al. towards a rigidity of BSC:

"First, the BSC is a measurement tool that is relatively rigid. The four perspectives are the main categories, according to which key success factors are defined. In consequence, the BSC tends to force indicators into one of the four perspectives" (Voelpel et al., 2006, p. 50).

Answer by Kaplan and Norton:

"With hundreds of enterprises around the world, and especially those identified for membership in the Balanced Scorecard Hall of Fame, none of them found the four perspective framework to have been forced upon them. They found it to be robust and flexible for describing and communicating their new strategies" (Kaplan \& Norton, 2006, p. 422).

- Critique by Voelpel et al. towards a staticism of BSC:

"Second, the BSC creates a static-ism that tends to struggle with the challenges of highly competitive and changing world ... it limits any further activities and initiatives that might go beyond the originally-set targets" (Voelpel et al., 2006, p. 50).

Answer by Kaplan and Norton:

"We have always advocated that companies use the Balanced Scorecard as an opportunity to learn and adapt their strategies to changing knowledge and economic conditions, and be responsive to new ideas emerging from within the organization" (Kaplan \& Norton, 2006, p. 422).

- Critique by Voelpel et al. towards an internally focused character of BSC:

"Third, the external innovative connectivity of an organization is hampered by the BSC, which is mostly an internal document; this is a critical limitation in its ability to account for the external environment and systemic linkages" (Voelpel et al., 2006, p. 51).

Answer by Kaplan and Norton:

"While not available to Voelpel et al., in our most recent book, Alignment (2006), we include an entire chapter, "Aligning External Partners." In this chapter, we advocate and describe how companies create strategy maps and scorecards with strategic suppliers, customers, and alliance partners. The critique that the Balanced Scorecard has an internal focus and cannot incorporate external relationships is refuted many times over in our writings" (Kaplan \& Norton, 2006, p. 425).

- Critique by Voelpel et al. towards a lack of innovation support of BSC:

"Fourth, yet another limitation of the BSC is the way that it deals with knowledge creation, learning and growth" (Voelpel et al., 2006, p. 54).

Answer by Kaplan and Norton:

"That the Balanced Scorecard can not incorporate innovation is a misrepresentation that Voelpel et al. could only have made by systematically ignoring all the references and priority we have placed on innovation in three books and many articles" (Kaplan \& Norton, 2006, p. 425).

- Critique by Voelpel et al. towards a mechanistic perspective of BSC: 
"Fifth, and finally, the BSC is grounded in a mechanistic mindset" (Voelpel et al., 2006, p. 54).

"While few companies have, to date, extended the linear hypotheses in their strategy maps into a dynamic, nonlinear simulation model, we have continually believed this is a natural extension to the Balanced Scorecard for companies with extensive data bases and strong analytic capabilities" (Kaplan \& Norton, 2006, p. 427).

Kaplan and Norton (2006) conclude in this "critique of critique" that Voelpel et al. do not provide examples of a company that has implemented and found useful their suggested "systemic" scorecard. They add that (Kaplan \& Norton, 2006, p. 428): "Apart from inadequate reading of the existing literature, the authors [Voelpel et al.] encourage companies to abandon an approach whose success has been publicly documented in several hundred enterprises around the world for their new model, which they themselves have apparently neither documented nor tested in a single company." Kaplan has also offered to answer to other reviews and commentaries the balanced scorecard received. As he states in response to Salterio's (2012) perspective that the balanced scorecard was a teaching development in management accounting, Kaplan (2012) argues that the balanced scorecard was primarily an innovation in management theory and practice. Kaplan also refutes Modell's (2012) view, which implies that the balanced scorecard approach is top-down, based on a strict hierarchical structure, by stating that the strategic map and the scorecard communicate the outcomes to be accomplished, allowing innovation at the middle and lower levels of the organization. Kaplan (2012, p. 542) also wonders how the balanced scorecard qualifies to be a "myth," according to Nørreklit et al. (2012), "when it has been successfully implemented by thousands of for-profit, nonprofit and public sector enterprises and has been regularly listed as among the top ten management tools used throughout the world."

More recently, other views and commentaries have appeared, which study the vast literature of the balanced scorecard framework. Hoque (2014) points out that through the study of relevant publications over the past 20 years, it appears that some organizations have difficulty integrating the balanced scorecard with other management control instruments, such as budgeting, and, as a result, they tend to use a large number of measures on a single scorecard, which lead to measuring the wrong things and reducing efficiency. Similarly, Lueg and Silva (2017) find that the balanced scorecard is versatile, as it can be applied to various industries, functions and hierarchies. However, they argue, the effectiveness and sophisticated implementation of these "modifications" (such as a balanced scorecard for SMEs) is still an open field under investigation. To the extent that SMEs lack a long-term strategic orientation, these companies can only have insufficient knowledge about performance measurement in general and, therefore, they are incapable of recognizing the benefits from using this tool (Hudson et al., 2001; Hvolby and Thorstenson, 2001). Finally, Laury et al. (2020) find that many extensions of the balanced scorecard have been introduced to make it more representative and workable, enabling new effective combinations with other performance measurement methodologies (Van Looy and Shafagatova, 2016).

In reaching the first conclusions following this presentation of the balanced scorecard model and the criticism it has received, we understand that it is a strategic control and performance measurement method, which, however, does not take into consideration in the same open way the variety of qualitative dimensions that the strategic audit methodologies suggest. As a result, open strategic audit questions are only oriented towards companies that already have enough developed measurement systems (and are high-performing companies, according to Kaplan and Norton). In the same context, as it is a widespread performance measurement practice, particularly in well-established companies, the balanced scorecard approach is rightly geared to answering four general perspectives in order for these firms to adapt better to their environment. It does not lack dynamics; we just need to recognize that it is aimed restrictively at high-performing companies, although it has elements that could be used in other firms as well. If we use Kaplan and Norton's cockpit metaphor, then it seems to us that it is of utmost importance how smaller and less well-equipped in control systems companies (in the metaphor, a single-seater airplane with a minimal cockpit system) manage to build individual scorecards. We appreciate that this could be useful, especially for insufficiently developed organizations operating in less advanced socio-economic spatial frameworks in which high-performing companies do not thrive (Pylak, 2015; Rodríguez-Pose and Wilkie, 2019; Trippl et al., 2016; Vlados et al., 2019).

Nevertheless, we should also note other limitations that derive from the scorecards' standard application. Specifically, illustrating the percentage change of a specialized variable in one of the scorecard dimensions (for example, customer service) has quite different content from an overall comprehension of how strategy evolves and mutates over time. Instead, it seems that it is more beneficial to emphasize the profound qualitative dimensions of a socio-economic organization, which may not have the clarity of quantitative measurements but enable a more precise and integrated image of each "organism's" structural evolution. 
With the approach we present in the following sections, we argue that we can treat the following critical points by venturing on a synchronous focus on strategic audit and financial indicators measurement. The fundamental points where we find the criticisms valid that also leave space for enriching the standard scorecard model are the following five. The standard balanced scorecard framework:

1. It focuses on critical aspects of a business, but not the most significant and synthesizing. Beyond strategy, it does not address in detail the dimensions of technology and management choices and operations and how they are co-mutated with strategy.

2. It does not offer a holistic framework for understanding where a firm's innovativeness is structured, considering the innovation and learning perspective as relatively independent.

3. It uses specific indicators and metrics that too many companies either do not apply or are exceedingly difficult to be implemented effectively. The possibility of applying such specialized "pilot cockpit" measurements to SMEs is not a realistic possibility for various such firms. However, we should notice that micro-enterprises (family businesses and other traditional forms of entrepreneurship) cannot articulate scorecards since they do not have the means and knowledge to mine and analyze complex financial and operational indicators (innovative startups seem to be an exception).

4. It does not make the most of a qualitative approach to examining a company's overall efficiency through participatory dialogue processes. Therefore, it cannot function as a process of strengthening strategic learning (see, for example, Hamel \& Prahalad, 1993).

5. It does not understand the firm's evolutionary dynamics within the trajectory of its specific external socio-economic environment. In other words, it lacks an evolutionary perspective in approaching the organization's core competence and competitiveness.

\section{The Stra.Tech.Man Approach: Dimensions and Mechanisms}

From our perspective, strategic audit and performance measurement should answer the questions of physiological evolution in Stra.Tech.Man terms (strategy-technology-management synthesis). As suggested in the past (Vlados, 2004, 2012, 2016; Vlados and Chatzinikolaou, 2019a), the Stra.Tech.Man framework is a business consulting instrument that diagnoses the firm's physiology, in the sense that each socio-economic organization has specific environmental and physiological boundaries, determined by the idiosyncratic ways it effectively synthesizes the co-evolving spheres of its strategy, technology, and management. According to the Stra.Tech.Man approach, competitive success and development is not exclusively a matter of the narrowly understood strategy; it is a matter, at the same time, of the effective composition of strategy and technology and management. Inadequacies in technology and management spheres make it difficult and often ineffective to implement the selected strategy. In other words, to avoid "unexpected" failures when implementing strategy, the limits set by the level of competence of the company's technological and management ability must always be analyzed and understood. Therefore, the "game of competitive survival" remains dialectical and evolutionary in all three Stra.Tech.Man internal spheres of the organization.

In this context, we aim to examine the Stra.Tech.Man approach as a possibly more thorough or complementary of the balanced scorecard concept. The Stra.Tech.Man approach suggests that, in the background, all firms are "living organisms," being infertile and ineffective to be treated as "machines" (Boulding, 1981; Boyer and Saillard, 1995; Coriat and Dosi, 2002; Coriat and Weinstein, 1995; Lordon, 1993; Nelson and Winter, 1982; Zeleny, 1981). This Stra.Tech.Man theoretical framework was first formulated in Vlados' (2004) doctoral dissertation, suggesting that the "heart" of every "living" firm lies in its evolutionary core and within the three spheres of strategy, technology and management. In this direction, every firm produces and reproduces these structural spheres to achieve efficient innovation, which will enable its survival and development within the ever-evolving external and internal environment (Figure 4). 


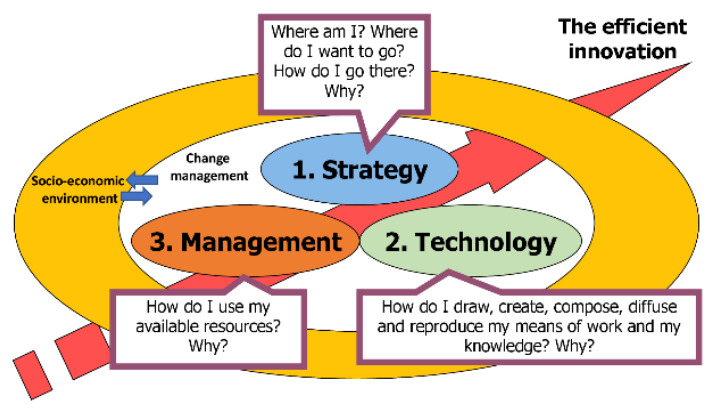

Figure 4. The firm's core

There are three series of questions that correspond to the combined interpretive perspective of the Stra.Tech.Man approach:

I. Strategy: Where am I? Where do I want to go? How do I go there? Why?

II. Technology: How do I draw, create, compose, diffuse, and reproduce my means of work and my knowledge? Why?

III. Management: How do I use my available resources? Why?

In a continuous and dialectical way, these components define the specific, idiosyncratic, and continually evolving, dynamic Stra.Tech.Man triangle of the firm under the ever-changing requirements of its ever-mutating environment. This evolutionary triangle defines the "DNA" of every firm, irrespectively of size, type, or industry. Every socio-economic organization forms its specific Stra.Tech.Man triangle to innovate efficiently and thus to profit. Even though this "core" regulates, in the background, the entire evolutionary trajectory of the firm, the three spheres are understood in the relevant scientific debate, quite wrongly, as inherently independent, autonomous, and functionally separated. On the contrary, we argue that these dimensions are always in a close relationship of evolutionary synthesis and "physiological" co-adaptation; all three together shape what we call the "evolutionary physiology of the firm."

In the context of empirical control of this study, which initially focused on Greece's production ecosystem, it turned out that the Greek economy is one of a peculiar (or specific) "fauna." Every successful firm within this socio-economic system, regardless of its type and sectoral orientation, is led to the Stra.Tech.Man syntheses "allowed" by its specific evolutionary physiology by implementing idiosyncratic business rationality, and, in this way, it reproduces its very heterogeneousness (Note 3). From the Stra.Tech.Man perspective, the firm's physiological evolution (and mutation) is the analytical epicenter of the entire innovation and development process; this is the engine of the constant change of both the firm and the surrounding socio-economic environment.

\section{The Stra.Tech.Man Scorecard}

In this direction, we suggest a rearranged business consulting, strategic audit, and performance measurement approach, method, and instrument: the Stra.Tech.Man Scorecard. On an annual basis, with this tool, all senior managers within the company can examine how the core functions evolve in terms of strategy, technology, and management. The goal is to participate in the development of the overall Stra.Tech.Man potential. In the next step, they can realize how the amelioration or worsening of the financial results relates to the Stra.Tech.Man partial dimensions.

This investigation aims not to create a predictive model but, on the contrary, an interpreting and mapping method capable of combining the innovative potential in Stra.Tech.Man terms with financial results as a way of capturing the company's annual effort in all of the examined dimensions. These annual qualitative and quantitative impressions can accumulate and record over time specific patterns and business profiles; in other words, to reflect under what conditions takes place the amelioration of Stra.Tech.Man dimensions and how this effort corresponds to key financial indicators' evolution, based on useful aspects extracted from the relevant literature. In Figure 5, we summarize the scorecard's structure, while Table 2 in Appendix A presents the questionnaire's overall analytical structure and steps. 


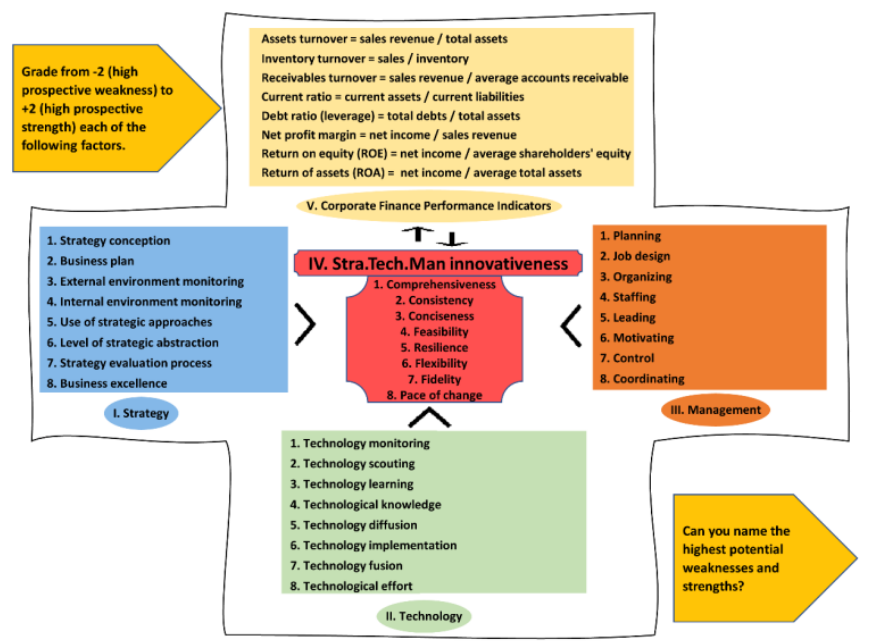

Figure 5. The extended Stra.Tech.Man methodology of strategic audit

At every level, at the strategy, technology, management, and financial performance, the Stra.Tech.Man score could take a grade of minus two to plus two, indicating high prospective weakness and high prospective strength, respectively, on each factor. The question is, where do the firm's people can name the highest potential weaknesses and strengths? Table 2 (Appendix B) presents each step of the Stra.Tech.Man Scorecard that ventures on monitoring all these aspects.

\section{Conclusions and Prospects of Implementing Field Research}

This article attempted to discern elliptically the virtues and limitations of standard formulations of strategic control, strategic audit, and Kaplan and Norton's balanced scorecard and counter-propose a repositioned framework based on the Stra.Tech.Man approach (strategy-technology-management synthesis) - the Stra.Tech.Man Scorecard. We arrive at the following conclusions:

- The standard balanced scorecard approach has been implemented within primarily larger and more advanced organizations, which already have typically developed performance measurement mechanisms. In this context, it requires a wealth of data, which small and medium-sized enterprises usually cannot collect, classify, and analyze. On the contrary, the Stra.Tech.Man approach can distinguish the evolution of specific types of business physiology without limitations related to the organization's size, structure, and measuring capabilities. The Stra.Tech.Man questions ("Where am I? Where do I want to go? How do I go there? How do I draw, create, compose, diffuse and reproduce my means of work and my knowledge? How do I use my available resources? Why?") have the ability to be universally implemented in every type of organization and holistically describe the general competitiveness guidelines for the "development control" of all socio-economic organizations.

- The standard balanced scorecard approach does not offer a compound understanding of a firm's central innovativeness Stra.Tech.Man potential that can be linked to the specific financial results. This gap can be filled by the counter-proposed Stra.Tech.Man Scorecard, which has been used experimentally as a business consulting tool in the past (in a less refined version), with quite interesting results to various small businesses (Vlados and Chatzinikolaou, 2019a, 2019b; Vlados et al., 2019).

- The standard balanced scorecard approach does not help create and monitor the different profiles of the firms' evolutionary physiologies. In this context, it cannot perceive the studied organization's continuous evolutionary formulation simultaneously with the overall changes of the socio-economic agglomerations surrounding it (Vlados and Chatzinikolaou, 2019c). In other words, it focuses only on strengthening the "micro" dimension of the examined organization without fully addressing the dynamics of the "meso" level—localities, clusters, business ecosystems, such as Porter's diamond approach (Porter, 1990; Vlados, 2019b) - and the "macro" environment that define the horizon of its necessary adaptations eventually. Instead, the Stra.Tech.Man approach manages to a significant extent a multi-level analysis.

The primary point that appears as a future research prospect is selecting a specific board of directors and focus groups of companies for confirming and deepening the proposed model's functionality in practice in this presented 
developed version. This suggested method could be applied in the future within various sectors of economic activity (industries) and in a variety of spatial socio-economic environments, covering a broader and more thorough experimental horizon, to effectively reflect its usefulness in the field and its limitations as a tool of assisting decision-making of different types of organizations.

\section{Acknowledgment}

Thanks go to Dimos Chatzinikolaou, Ph.D. Candidate at the Department of Economics of the Democritus University of Thrace for his help editing this text. I also warmly thank Dr. Andreas Andrikopoulos, Associate Professor at the Department of Business Administration of the University of the Aegean, who offered valuable comments on this manuscript's last version.

\section{References}

Abdullah, N. H., Shamsuddin, A., Wahab, E., \& Hamid, N. A. A. (2014). The relationship between organizational culture and product innovativeness. Procedia - Social and Behavioral Sciences, 129, 140-147. https://doi.org/10.1016/j.sbspro.2014.03.659

Allen, P., Maguire, S., \& McKelvey, B. (2011). The SAGE handbook of complexity and management. SAGE, Los Angeles; London; New Delhi; Singapore; Washington DC.

Andrikopoulos, A., Merika, A. A., Triantafyllou, A., \& Merikas, A. G. (2013). Internet disclosure and corporate performance: A case study of the international shipping industry. Transportation Research Part A: Policy and Practice, 47, 141-152. https://doi.org/10.1016/j.tra.2012.10.016

Ansoff, H. I., Bursk, E. C., \& Conference Board. (1973). Management in transition. Challenge to leadership: managing a changing world (pp. 22-63). Free Press, New York, US.

Argyris, C. (1952). The impact of budgets on people. Controllership Foundation, New York, US.

Beer, M. (1980). Organization Change and Development: A Systems View. Goodyear Pub. Co., Santa Monica, CA, US.

Beer, S. (1972). Brain of the firm: the managerial cybernetics of organization. Allen Lane, Penguin, London, UK.

Bell, G. (2020). The organizational resilience handbook: a practical guide to achieving greater resilience. Kogan Page Publishers, London, UK.

Bernus, P., Nemes, L., \& Schmidt, G. (2012). Handbook on enterprise architecture. Springer Science \& Business Media, Berlin, Heidelberg.

Beuren, I. M., \& Dal Vesco, D. G. (2021). Management control systems and performance in strategic supply relationships. International Journal of Productivity and Performance Management. https://doi.org/10.1108/JJPPM-01-2020-0036

Boulding, K. E. (1981). Evolutionary economics. Sage Publications, London, UK.

Bourguignon, A., Malleret, V., \& Nørreklit, H. (2004). The American balanced scorecard versus the French tableau de bord: the ideological dimension. Management Accounting Research, 15(2), 107-134.

Boyer, R., \& Saillard, Y. (1995). Théorie de la régulation: L'ètat des savoirs. La Découverte, Paris.

Brignall, S. (2002). The balanced scorecard: An environmental and social critique. Proceedings of the 3rd International Conference on Performance Measurement, Boston, MA.

Cardoni, A., Tompson, G. H., Rubino, M., \& Taticchi, P. (2020). Measuring the impact of organizational complexity, planning and control on strategic alliances' performance. Measuring Business Excellence, 24(4), 531-551. https://doi.org/10.1108/MBE-02-2020-0023

Chandler, A. D. (1977). The visible hand: the managerial revolution in American business. Belknap, Cambridge, MA, US.

Chapman, C. S. (2005). Controlling strategy: management, accounting, and performance measurement. OUP Oxford, Oxford, New York, US.

Chen, C. C., Liu, J. Y.-C., \& Chen, H.-G. (2011). Discriminative effect of user influence and user responsibility on information system development processes and project management. Information and Software Technology, 53(2), 149-158. https://doi.org/10.1016/j.infsof.2010.10.001 
Conrad, C., \& Poole, M. S. (2012). Strategic organizational communication: In a global economy. John Wiley \& Sons, Chichester, West Sussex, UK.

Coriat, B., \& Dosi, G. (2002). Évolutionnisme et régulation: différences et convergences. La Découverte, Paris.

Coriat, B., \& Weinstein, O. (1995). Les Nouvelles Théories De L'entreprise. LGF - Livre de Poche, Paris.

Doan, Q. M., Rosenthal-Sabroux, C., \& Grundstein, M. (2011). A reference model for knowledge retention within Small and Medium-Sized Enterprises. Presented at the KMIS 2011-Proceedings of the International Conference on Knowledge Management and Information Sharing (pp. 306-311).

Donaldson, G. (1995). A new tool for boards: The strategic audit. Harvard Business Review, 73(4), 99-108.

Drucker, P. (1954). The practice of management. Harper, New York, US.

Epstein, M. J., \& Manzoni, J.-F. (1997). The balanced scorecard and tableau de bord: Translating strategy into action. The European Institute of Business Administration, 79(2), 28-36.

Epstein, M. J., Manzoni, J.-F., \& Davila, A. (2010). Performance measurement and management control: innovative concepts and practices. Emerald Group Publishing, Bingley, UK.

Fayol, H. (1949). General and industrial management. Sir Isaac Pitman \& Sons, London, UK.

Fernández-Guerrero, R., Revuelto-Taboada, L., \& Simón-Moya, V. (2012). The business plan as a project: An evaluation of its predictive capability for business success. The Service Industries Journal, 32(15), 2399-2420. https://doi.org/10.1080/02642069.2012.677830

Fliedner, G. (2011). Leading and Managing the Lean Management Process. Business Expert Press, New York, US. https://doi.org/10.4128/9781606492482

García-Sánchez, I.-M., Suárez-Fernández, O., \& Martínez-Ferrero, J. (2019). Female directors and impression management in sustainability reporting. International Business Review, 28(2), 359-374. https://doi.org/10.1016/j.ibusrev.2018.10.007

Gilson, L. L., \& Goldberg, C. B. (2015). Editors' comment: So, what is a conceptual paper?. Group \& Organization Management, 40(2), 127-130. https://doi.org/10.1177/1059601115576425

Goold, M., \& Quinn, J. J. (1990). The paradox of strategic controls. Strategic Management Journal, 11(1), 43-57. https://doi.org/10.1002/smj.4250110104

Gordon, P. J. (1997). Ten strategic audit questions. Business Horizons, 40(5), 7-14. https://doi.org/10.1016/S0007-6813(97)90081-1

Griffin, R. W. (2012). Management fundamentals. South-Western Cengage Learning, Australia; Singapore.

Grundy, T. (2008). Highlighting blind spots. Accountancy Magazine, Institute of Chartered Accountants, 1373, 44-46.

Hamel, G., \& Prahalad, C. K. (1993). Strategy as stretch and leverage. Harvard Business Review, 71(2), 75-84.

Hoque, Z. (2014). 20 years of studies on the balanced scorecard: Trends, accomplishments, gaps and opportunities for future research. The British Accounting Review, 46(1), 33-59. https://doi.org/10.1016/j.bar.2013.10.003

Horovitz, J. H. (1979). Strategic control: A new task for top management. Long Range Planning, 12(3), 2-7. https://doi.org/10.1016/S0024-6301(79)80001-1

Hudson, M., Smart, A., \& Bourne, M. (2001). Theory and practice in SME performance measurement systems. International Journal of Operations \& Production Management, 21(8), 1096-1115. https://doi.org/10.1108/EUM0000000005587

Hunger, J. D., \& Wheelen, T. L. (1996). Essentials of strategic management. Addison-Wesley, Reading, MA, US.

Hvolby, H.-H., \& Thorstenson, A. (2001). Indicators for performance measurement in small and medium-sized enterprises. Proceedings of the Institution of Mechanical Engineers, Part B. Journal of Engineering Manufacture, 215(8), 1143-1146. https://doi.org/10.1243/0954405011518926

Jaakkola, E. (2020). Designing conceptual articles: Four approaches. AMS Review, 10(1), 18-26. https://doi.org/10.1007/s13162-020-00161-0 
Jansen, S., Cusumano, M. A., \& Brinkkemper, S. (2013). Software ecosystems: analyzing and managing business networks in the software industry. Edward Elgar Publishing, Cheltenham, UK; Northampton, MA, US. https://doi.org/10.4337/9781781955635

Johnson, J. A., \& Davey, K. S. (2019). Essentials of managing public health organizations. Jones \& Bartlett Learning, Burlington, MA, US.

Kaplan, R. E., \& Norton, D. P. (2004). Strategy maps: converting intangible assets into tangible outcomes. Harvard Business School, Boston, MA.

Kaplan, R. S. (2012). The balanced scorecard: Comments on balanced scorecard commentaries. Journal of Accounting \& Organizational Change, 8(4), 539-545. https://doi.org/10.1108/18325911211273527

Kaplan, R. S., \& Norton, D. P. (1992). The balanced scorecard-measures that drive performance. Harvard Business Review, No. January-February 1992.

Kaplan, R. S., \& Norton, D. P. (1996). The balanced scorecard: translating strategy into action. Harvard Business School Press, Boston, MA.

Kaplan, R. S., \& Norton, D. P. (2001). The strategy focused organization: how balanced scorecard companies thrive in the new business environment. Harvard Business School, Boston.

Kaplan, R. S., \& Norton, D. P. (2006). The tyranny of the Balanced Scorecard in the innovation economy. Journal of Intellectual Capital, 7(1), 43-60. https://doi.org/10.1108/14691930610639769

Kaplan, R. S., \& Norton, D. P. (2008). Execution premium: linking strategy to operations for competitive advantage. Harvard Business Press, Boston, MA.

Katamei, J. M., Omwono, G. A., \& Wanza, S. L. (2015). Challenges of strategy implementation on performance of constituency development fund projects in Kenya: a case of Marakwet west constituency. International Journal of Business Administration, 6(3), 48-62. https://doi.org/10.5430/ijba.v6n3p48

Kenny, K., Vandekerckhove, W., \& Fotaki, M. (2019). The whistleblowing guide: speak-up arrangements, challenges and best practices. John Wiley \& Sons, Chichester, West Sussex, UK. https://doi.org/10.1002/9781119360742

Keser Ozmantar, Z., \& Gedikoglu, T. (2016). Design principles for the development of the balanced scorecard. International Journal of Educational Management, 30(5), 622-634. https://doi.org/10.1108/IJEM-01-2015-0005

Khan, M. Y., \& Jain, P. K. (2013). Management accounting: text, problems and cases. McGraw-Hill Education (India), New Delhi, India.

Koontz, H. (1958). A preliminary statement of principles of planning and control. Academy of Management Journal, 1(1), 45-61. https://doi.org/10.5465/254580

Laury, H. A., Matondang, N., \& Sembiring, M. T. (2020). Balanced scorecard in the integration of corporate strategic planning and performance: A literature review. IOP Conference Series: Materials Science and Engineering, 801, 012135. https://doi.org/10.1088/1757-899X/801/1/012135

Lawrie, G., \& Cobbold, I. (2004). Third-generation balanced scorecard: Evolution of an effective strategic control tool. International Journal of Productivity and Performance Management, 53(7), 611-623. https://doi.org/10.1108/17410400410561231

Li, Q., Yang, W., \& Li, K. (2018). Role of social learning in the diffusion of environmentally-friendly agricultural technology in China. Sustainability, Multidisciplinary Digital Publishing Institute, 10(5), 1527. https://doi.org/10.3390/su10051527

Lorange, P., \& Morton, M. S. S. (1974). A framework for management control systems. Sloan Management Review (Pre-1986), 16(3), 41-56.

Lordon, F. (1993). Irrégularités Des Trajectoires De Croissance Évolutions Et Dynamique Non-Linéaire: Vers Une Schématisation De L'endométabolisme. EHESS, Paris.

Lueg, R., \& Silva, A. L. C. E. (2017). When one size does not fit all: A literature review on the modifications of the balanced scorecard. Problems and Perspectives in Management, 11(3), 86-94.

Madsen, D. Ø., \& Stenheim, T. (2015). The Balanced Scorecard: A review of five research areas. American Journal of Management, 15(2), 24-41. https://doi.org/10.18374/RBR-15-3.8 
Mahadeen, B., Al-Dmour, R. H., Obeidat, B. Y., \& Tarhini, A. (2016). Examining the effect of the organization's internal control system on organizational effectiveness: A Jordanian empirical study. International Journal of Business Administration, 7(6), 22-41. https://doi.org/10.5430/ijba.v7n6p22

Meyer, C., \& Davis, S. M. (2003). It's alive: The coming convergence of information, biology, and business. Crown Business, New York, US.

Millar, J., Demaid, A., \& Quintas, P. (1997). Trans-organizational innovation: A framework for research. Technology Analysis \& Strategic Management, 9(4), 399-418. https://doi.org/10.1080/09537329708524294

Modell, S. (2012). The politics of the balanced scorecard. Journal of Accounting \& Organizational Change, 8(4), 475-489. https://doi.org/10.1108/18325911211273482

Nandakumar, M. K., Jharkharia, S., \& Nair, A. S. (2014). Organisational flexibility and competitiveness. Springer Science \& Business Media, New Delhi, India. https://doi.org/10.1007/978-81-322-1668-1

Neely, A. (2005). The evolution of performance measurement research: Developments in the last decade and a research agenda for the next. International Journal of Operations \& Production Management, 25(12), 1264-1277. https://doi.org/10.1108/01443570510633648

Nelson, R., \& Winter, S. (1982). An evolutionary theory of economic change. The Belknap Press of Harvard University Press, Cambridge, MA; London, UK.

Newman, W. H. (1975). Constructive control: design and use of control systems. Prentice Hall, Englewood Cliffs, NJ, US.

Norreklit, H. (2000). The balance on the balanced scorecard: A critical analysis of some of its assumptions. Management Accounting Research, 11(1), 65-88. https://doi.org/10.1006/mare.1999.0121

Nørreklit, H., Nørreklit, L., Mitchell, F., \& Bjørnenak, T. (2012). The rise of the balanced scorecard! Relevance regained?. Journal of Accounting \& Organizational Change, 8(4), 490-510. https://doi.org/10.1108/18325911211273491

Norton, D. P., \& Kaplan, R. S. (2006). Alignment: using the balanced scorecard to create corporate synergies. Harvard Business School Press, Boston, MA.

Ordóñez de Pablos, P. (2016). Managerial Strategies and Solutions for Business Success in Asia. IGI Global, Hershey, PA, US. https://doi.org/10.4018/978-1-5225-1886-0

Perkins, M., Grey, A., \& Remmers, H. (2014). What do we really mean by 'balanced scorecard'?. International Journal of Productivity and Performance Management, 63(2), 148-169. https://doi.org/10.1108/IJPPM-11-2012-0127

Porter, M. (1990). The competitive advantage of nations (1st ed.). Free Press, New York. https://doi.org/10.1007/978-1-349-11336-1_1

Pylak, K. (2015). Changing innovation process models: a chance to break out of path dependency for less developed regions. Regional Studies, Regional Science, 2(1), 46-72. https://doi.org/10.1080/21681376.2014.979433

Reeves, M., Levin, S., \& Ueda, D. (2016). The biology of corporate survival. Harvard Business Review, 94(1/2), 46-57.

Respício, A., Adam, F., Phillips-Wren, G., Telhada, J., \& Teixeira, C. (2010). Bridging the socio-technical gap in decision support systems: challenges for the next decade. IOS Press, Amsterdam; Berlin; Tokyo; Washington, DC.

Ridgway, V. F. (1956). Dysfunctional consequences of performance measurements. Administrative Science Quarterly, 1(2), 240-247. https://doi.org/10.2307/2390989

Robbins, S. P., Coulter, M. K., \& DeCenzo, D. A. (2020). Fundamentals of management. Pearson, Harlow, UK.

Rodríguez-Pose, A., \& Wilkie, C. (2019). Innovating in less developed regions: What drives patenting in the lagging regions of Europe and North America. Growth and Change, 50(1), 4-37. https://doi.org/10.1111/grow.12280

Ruefli, T., \& Sarrazin, J. (1981). Strategic control of corporate development under ambiguous circumstances. Management Science, 27(10), 1158-1170. https://doi.org/10.1287/mnsc.27.10.1158

Runiewicz-Wardyn, M. (2013). Knowledge flows, technological change and regional growth in the European Union. Springer Science \& Business Media, Cham, Switzerland. https://doi.org/10.1007/978-3-319-00342-9 
Safdari Ranjbar, M., \& Tavakoli, G. R. (2015). Toward an inclusive understanding of technology intelligence: a literature review. Foresight, 17(3), 240-256. https://doi.org/10.1108/FS-11-2014-0072

Salterio, S. (2012). Balancing the scorecard through academic accounting research: Opportunity lost?. Journal of Accounting \& Organizational Change, 8(4), 458-474. https://doi.org/10.1108/18325911211273473

Schendel, D. (1979). Strategic management: A new view of business policy and planning. Little, Brown and Company, Boston, MA, US.

Schendel, D. E., \& Hatten, K. J. (1972). Business policy or strategic management: A broader view for an emerging discipline. Academy of Management Proceedings, 1972, 99-102. https://doi.org/10.5465/ambpp.1972.4981324

Sedysheva, M. (2012). Strategic management system and methods of controlling as key elements of military expenditure policy-making process. Journal of Strategy and Management, 5(3), 353-368. https://doi.org/10.1108/17554251211247607

Seifzadeh, P., \& Rowe, W. G. (2019). The role of corporate controls and business-level strategy in business unit performance. Journal of Strategy and Management, 12(3), 364-381. https://doi.org/10.1108/JSMA-10-2018-0114

Shaw, A., McPhail, R., \& Ressia, S. (2018). Employment relations. Cengage AU.

Skyrius, R. (2016). Business information: needs and satisfaction. Informing Science, Santa Rosa, CA, US.

Smith, M., \& Loonam, J. (2016). Exploring strategic execution: A case study on the use of the balanced scorecard within an Irish hospital. Journal of Strategy and Management, 9(4), 406-428. https://doi.org/10.1108/JSMA-11-2015-0094

Srivastava, M. K., Gnyawali, D. R., \& Hatfield, D. E. (2015). Behavioral implications of absorptive capacity: The role of technological effort and technological capability in leveraging alliance network technological resources. Technological Forecasting and Social Change, 92, 346-358. https://doi.org/10.1016/j.techfore.2015.01.010

Stone, T. L. (2010). Managing the design process: implementing design: an essential manual for the working designer. Rockport Publishers, Beverly, MA, US.

Taylor, B. (1973). Introducing strategic management. Long Range Planning, 6(3), 34-38. https://doi.org/10.1016/0024-6301(83)90183-8

Teti, K., Yang, M.-J., Bloom, N., Rivkin, J., \& Sadun, R. (2017). The different approaches firms use to set strategy. Harvard Business Review, 1-7.

Trippl, M., Asheim, B., \& Miörner, J. (2016). Identification of regions with less-developed research and innovation systems. Innovation Drivers and Regional Innovation Strategies, 23-44.

Umeda, S., Nakano, M., Mizuyama, H., Hibino, H., Kiritsis, D., \& Von Cieminski, G. (2015). Advances in Production Management Systems: Innovative Production Management Towards Sustainable Growth: IFIP WG 5.7 International Conference, APMS 2015, Tokyo, Japan, September 7-9, 2015, Proceedings, Part II (Vol. 460). Springer International Publishing, Cham. https://doi.org/10.1007/978-3-319-22759-7

Valmohammadi, C., \& Sofiyabadi, J. (2015). Modeling cause and effect relationships of strategy map using fuzzy DEMATEL and fourth generation of balanced scorecard. Benchmarking: An International Journal, 22(6), 1175-1191. https://doi.org/10.1108/BIJ-09-2014-0086

Van Looy, A., \& Shafagatova, A. (2016). Business process performance measurement: A structured literature review of indicators, measures and metrics. Springer Plus, 5(1), 1797. https://doi.org/10.1186/s40064-016-3498-1

Vlados, Ch. (2004). La dynamique du triangle stratégie, technologie et management: l'insertion des entreprises grecques dans la globalisation. Thèse de doctorat de Sciences Économiques, Université de Paris X-Nanterre, 1 January.

Vlados, Ch. (2012). The search of competitiveness and the entrepreneurial evolution in a global environment: Toward a new approach of development dynamics based on the case of Greek productive system. Journal of Management Sciences and Regional Development, (8), 91-116. https://doi.org/10.2139/ssrn.3218008

Vlados, Ch. (2016). Strategy of small and medium-sized enterprises: The Stra.Tech.Man approach. Kritiki Publications, Athens, Greece. 
Vlados, Ch. (2019a). Change management and innovation in the "living organization": The Stra.Tech.Man approach. Management Dynamics in the Knowledge Economy, 7(2), 229-256. https://doi.org/10.25019/MDKE/7.2.06

Vlados, Ch. (2019b). Porter's diamond approaches and the competitiveness web. International Journal of Business Administration, 10(5), 33-52. https://doi.org/10.5430/ijba.v10n5p33

Vlados, Ch., \& Chatzinikolaou, D. (2019a). Business ecosystems policy in Stra.Tech.Man terms: The case of the Eastern Macedonia and Thrace region. Journal of Entrepreneurship, Management and Innovation, 15(3), 163-197. https://doi.org/10.7341/20191536

Vlados, Ch., \& Chatzinikolaou, D. (2019b). Strategy perception and implementation on less developed business ecosystems micro and small enterprises: The service sector of Eastern Macedonia and Thrace. Business Management and Strategy, 10(2), 27-63. https://doi.org/10.5296/bms.v10i2.15008

Vlados, Ch., \& Chatzinikolaou, D. (2019c). Methodological redirections for an evolutionary approach of the external business environment. Journal of Management and Sustainability, 9(2), 25-46. https://doi.org/10.5539/jms.v9n2p25

Vlados, Ch., Chatzinikolaou, D., Katimertzopoulos, F., \& Koutroukis, T. (2019). Regional underdevelopment and less developed business ecosystems: The case of Eastern Macedonia and Thrace. Bulletin of Applied Economics, $6(2), 31-44$.

Vlasenko, T., Hatsko, A., Larina, T., Hryn, Y., Streimikiene, D., \& Balezentis, T. (2019). Fuzzy evaluation of change management processes in the context of enterprise sustainability. Sustainability, 11(22), 6310. https://doi.org/10.3390/su11226310

Voelpel, S. C., Leibold, M., \& Eckhoff, R. A. (2006). The tyranny of the Balanced Scorecard in the innovation economy. Journal of Intellectual Capital, 7(1), 43-60. https://doi.org/10.1108/14691930610639769

Wart, M. V. (2014). Dynamics of leadership in public service: theory and practice. Routledge, London, UK; New York, US. https://doi.org/10.4324/9781315705071

Wolfgang, R. (2014). Technology Entrepreneurship: A Treatise on Entrepreneurs and Entrepreneurship for and in Technology Ventures (Volume 2). KIT Scientific Publishing, Karlsruhe, Germany.

Zahradnickova, L., \& Vacik, E. (2011). The basic characteristics of successful business strategy. Presented at the Annals of DAAAM and Proceedings of the International DAAAM Symposium (pp. 1383-1384).

Zeleny, M. (1981). What is autopoiesis?. In M. Zeleny (Ed.), Autopoiesis: a theory of living organization (pp. 4-17). Elsevier North Holland, New York, N.Y.

\section{Notes}

Note 1. As an example, in the Scopus and Web of Science databases, a search for the phrase "strategic audit" from 2010 to 2020 returns only 21 and 8 results, respectively.

Note 2. There are other forms, streams, and generations in the relevant literature, with several variations in their content, interpretation, and representation (Keser Ozmantar and Gedikoglu, 2016; Lawrie and Cobbold, 2004; Perkins et al., 2014; Valmohammadi and Sofiyabadi, 2015). More specifically, four "generations" can be found, with the first three referring primarily to Kaplan and Norton's representations and practices, together with a different generation (fourth) expressed with various attributes and features in the practice of certain consulting firms.

Note 3. In the next analytical step, this continuous business movement co-creates and dynamically co-defines every aspect of the surrounding environment; here lies the very source of globalization's dynamics; in other words, the continuous adaption and innovative evolution of socio-economic organizations based on their distinct physiology decides the actual content and potential of the dynamics of globalization. 


\section{Appendix A}

\section{The Stra.Tech.Man Scorecard questionnaire}

Table A. The complete system of the Stra.Tech.Man Scorecard. This questionnaire is recommended as a diagnostic method for businesses running for five years or more since the available information is considered more reliable

\section{GENERAL INFORMATION}

\section{Firm name}

Website

\section{Email}

\section{Phone}

\section{Headquarters address}

\section{Date founded}

\section{Business description}

\section{Number of full-time employees}

Sector (Manufacturing; Service (includes retail, wholesale, distribution); Mining/Oil/Gas; Combined)

Distribution areas (Local; regional; national;
international) (\%)

\section{Key subsidiaries}

\section{Number of outlets}

QUESTIONNAIRE - Grade I, II, and III from -2 (high prospective weakness) to +2 (high prospective strength) each of the following factors.

\section{STRATEGY}

\section{S1. Strategy conception}

"Strategy conception is a decision-making process that enables a company to achieve its mission and vision" (Bernus et al., 2012, p. 347).

Self-evaluation concerning the present:

\begin{tabular}{lllll}
\hline-2 (worsening) & -1 & 0 & +1 & +2 (amelioration) \\
\hline Self-evaluation concerning the past: & & & +2 (amelioration) \\
\hline-2 (worsening) & -1 & 0 & +1 & +1
\end{tabular}

How has the general conception of strategy changed over the past year? What relevant actions and changes have taken place in this direction? Answer by giving specific examples (up to 100 words):

\section{S2. Business plan}

"The business plan is a mechanism used to project the firm into the future, to foresee difficulties and to identify possible solutions for the different situations that may arise, and makes it possible to reduce the project's risks by making decisions with more and better quality information, as well as enabling the firm to connect with its environment" (Fernández-Guerrero et al., 2012, p. 2403).

Self-evaluation concerning the present:

\begin{tabular}{lllll}
\hline-2 (worsening) & -1 & 0 & +1 & +2 (amelioration) \\
\hline Self-evaluation concerning the past: &
\end{tabular}

Self-evaluation concerning the past: 


\begin{tabular}{lllll}
\hline-2 (worsening) & -1 & 0 & +1 & +2 (amelioration)
\end{tabular}

How has the business plan changed over the past year? What relevant actions and changes have taken place in this direction? Answer by giving specific examples (up to 100 words):

\section{S3. External environment monitoring}

"The most often monitored groups of external information are opportunities and prospects; competition behavior; customer behavior. They reflect the competitive environment that is being monitored, and the monitoring priorities aim both for opportunities and threats" (Skyrius, 2016, p. 217).

Self-evaluation concerning the present:

\begin{tabular}{lllll}
\hline-2 (worsening) & -1 & 0 & +1 & +2 (amelioration) \\
\hline Self-evaluation concerning the past: & & & +2 (amelioration) \\
\hline-2 (worsening) & -1 & 0 & +1 & \\
\hline
\end{tabular}

How has the external environment monitoring changed over the past year? What relevant actions and changes have taken place in this direction? Answer by giving specific examples (up to 100 words):

\section{S4. Internal environment monitoring}

"During the [internal environment] monitoring process, diagnostics are performed, the results of which define a range of problems or tasks, which should be defined as another planning process at the initiation stage, which involves setting goals for implementation of changes and decomposing them to specific tasks" (Vlasenko et al., 2019, p. 3).

Self-evaluation concerning the present:

\begin{tabular}{lllll}
\hline-2 (worsening) & -1 & 0 & +1 & +2 (amelioration)
\end{tabular}

Self-evaluation concerning the past:

\begin{tabular}{lllll}
\hline-2 (worsening) & -1 & 0 & +1 & +2 (amelioration)
\end{tabular}

How has the internal environment monitoring changed over the past year? What relevant actions and changes have taken place in this direction? Answer by giving specific examples (up to 100 words):

\section{S5. Use of strategic approaches}

“Alternatives. Does the firm consider alternative options when making strategic decisions?" (Teti et al., 2017, p. 7).

Self-evaluation concerning the present:

\begin{tabular}{lllll}
\hline-2 (worsening) & -1 & 0 & +1 & +2 (amelioration) \\
\hline Self-evaluation concerning the past: & & & \\
\hline-2 (worsening) & -1 & 0 & +1 & +2 (amelioration)
\end{tabular}

How has the use of strategic approaches changed over the past year? What relevant actions and changes have taken place in this direction? Answer by giving specific examples (up to 100 words):

\section{S6. Level of strategic abstraction (mission, vision, philosophy)}

"The vision outlines the shape of the corporation in the future [...] The mission outlines the primary purpose of the firm [...] The philosophy incorporates organizational values and defines general principles [...] In which of the three complementary dimensions [...] do you think your organization has higher-level strategic processing?" (Vlados and Chatzinikolaou, 2019b, pp. 34-35).

Self-evaluation concerning the present:

\begin{tabular}{lllll}
\hline-2 (worsening) & -1 & 0 & +1 & +2 (amelioration)
\end{tabular}

Self-evaluation concerning the past: 


\begin{tabular}{lllll}
\hline-2 (worsening) & -1 & 0 & +1 & +2 (amelioration)
\end{tabular}

How has the level of strategic abstraction changed over the past year? What relevant actions and changes have taken place in this direction? Answer by giving specific examples (up to 100 words):

\section{S7. Strategy evaluation process}

"The strategy evaluation means the set of tools according to a statement whether the business strategy was successfully done" (Zahradnickova and Vacik, 2011, p. 1383).

Self-evaluation concerning the present:

-2 (worsening) $\quad-1$

$0+1$

$+1+2$ (amelioration)

Self-evaluation concerning the past:

\begin{tabular}{lllll}
\hline-2 (worsening) & -1 & 0 & +1 & +2 (amelioration)
\end{tabular}

How has strategy evaluation changed over the past year? What relevant actions and changes have taken place in this direction? Answer by giving specific examples (up to 100 words):

\section{S8. Business excellence}

"The fundamental concept of excellence is achieving balanced results through people's creativity and innovation. It means adding value for customers" (Ordóñez de Pablos, 2016, p. 64).

Self-evaluation concerning the present:

\begin{tabular}{lllll}
\hline-2 (worsening) & -1 & 0 & +1 & +2 (amelioration) \\
\hline Self-evaluation concerning the past: & 0 & +1 & +2 (amelioration) \\
\hline-2 (worsening) & -1 & 0 & \\
\hline How has business excellence changed over the past year? What relevant actions and changes have taken place in
\end{tabular}
this direction? Answer by giving specific examples (up to 100 words):

\section{TECHNOLOGY}

\section{T1. Technology monitoring}

"Technology monitoring: Refers to the constant process of following the latest identified technology trends to discover gaps and developments of technology" (Safdari Ranjbar and Tavakoli, 2015, p. 243).

Self-evaluation concerning the present:

\begin{tabular}{lllll}
\hline-2 (worsening) & -1 & 0 & +1 & +2 (amelioration) \\
\hline Self-evaluation concerning the past: & & & +2 (amelioration)
\end{tabular}

How has technology monitoring changed over the past year? What relevant actions and changes have taken place in this direction? Answer by giving specific examples (up to 100 words):

\section{T2. Technology scouting}

"Technology scouting is used to detect advances in technology at an early development stage including the identification and assessment of new technologies" (Jansen et al., 2013, p. 125).

Self-evaluation concerning the present:

\begin{tabular}{lllll}
\hline-2 (worsening) & -1 & 0 & +1 & +2 (amelioration) \\
\hline Self-evaluation concerning the past: & & & \\
\hline-2 (worsening) & -1 & 0 & +1 & +2 (amelioration)
\end{tabular}

How has technology scouting changed over the past year? What relevant actions and changes have taken place in this direction? Answer by giving specific examples (up to 100 words): 


\section{T3. Technology learning}

"Organizational technology learning refers to the technology knowledge or skill acquired by the interaction or activities of a firm" (Chen et al., 2011, p. 152).

Self-evaluation concerning the present:

\begin{tabular}{lllll}
\hline-2 (worsening) & -1 & 0 & +1 & +2 (amelioration) \\
\hline Self-evaluation concerning the past: & & & \\
\hline-2 (worsening) & -1 & 0 & +1 & +2 (amelioration)
\end{tabular}

How has technology learning changed over the past year? What relevant actions and changes have taken place in this direction? Answer by giving specific examples (up to 100 words):

\section{T4. Technological knowledge}

"Technological knowledge refers to all kinds of technical information, specifications, and know-how necessary to create and produce a product. Innovation and the exchange of technological knowledge are of utmost importance" (Runiewicz-Wardyn, 2013, p. 123).

Self-evaluation concerning the present:

-2 (worsening) $\quad-1$

0

$+1$

Self-evaluation concerning the past:

\begin{tabular}{lllll}
\hline-2 (worsening) & -1 & 0 & +1 & +2 (amelioration)
\end{tabular}

How has technological knowledge changed over the past year? What relevant actions and changes have taken place in this direction? Answer by giving specific examples (up to 100 words):

\section{T5. Technology diffusion}

"The diffusion of technology is realized through the interactive process of "learning" or "communication" between individuals. Therefore, the effective transmission of information is a prerequisite for achieving technology diffusion" (Li et al., 2018, p. 3).

Self-evaluation concerning the present:

\begin{tabular}{lllll}
\hline-2 (worsening) & -1 & 0 & +1 & +2 (amelioration)
\end{tabular}

Self-evaluation concerning the past:

\begin{tabular}{lllll}
\hline-2 (worsening) & -1 & 0 & +1 & +2 (amelioration)
\end{tabular}

How has technology diffusion changed over the past year? What relevant actions and changes have taken place in this direction? Answer by giving specific examples (up to 100 words):

\section{T6. Technology implementation}

"Technology implementation means selecting the techniques to target a given goal related to tools, goods, or services" (Wolfgang, 2014, p. 1215).

Self-evaluation concerning the present:

\begin{tabular}{lllll}
\hline-2 (worsening) & -1 & 0 & +1 & +2 (amelioration)
\end{tabular}

Self-evaluation concerning the past:

\begin{tabular}{lllll}
\hline-2 (worsening) & -1 & 0 & +1 & +2 (amelioration)
\end{tabular}

How has technology implementation changed over the past year? What relevant actions and changes have taken place in this direction? Answer by giving specific examples (up to 100 words):

\section{T7. Technology fusion}

"Technology fusion refers to the development of new technologies based on hybrid combinations of existing 
technologies." (Millar et al., 1997, p. 401).

Self-evaluation concerning the present:

\begin{tabular}{lllll}
\hline-2 (worsening) & -1 & 0 & +1 & +2 (amelioration)
\end{tabular}

Self-evaluation concerning the past:

\begin{tabular}{lllll}
\hline-2 (worsening) & -1 & 0 & +1 & +2 (amelioration)
\end{tabular}

How has technology fusion changed over the past year? What relevant actions and changes have taken place in this direction? Answer by giving specific examples (up to 100 words):

\section{T8. Technological effort}

"Technological effort refers to the extent to which a firm commits resources toward knowledge search and development. Higher efforts are indicative of a firm's motivation to explore new knowledge and tap into available knowledge acquisition opportunities" (Srivastava et al., 2015, p. 350).

Self-evaluation concerning the present:

\begin{tabular}{lllll}
\hline-2 (worsening) & -1 & 0 & +1 & +2 (amelioration) \\
\hline Self-evaluation concerning the past: & & & +2 (amelioration) \\
\hline-2 (worsening) & -1 & 0 & +1 & +1
\end{tabular}

How has the technological effort changed over the past year? What relevant actions and changes have taken place in this direction? Answer by giving specific examples (up to 100 words):

\section{MANAGEMENT}

\section{M1. Planning}

"Planning refers to establishing an organization's goals and plans to accomplish these goals. The planning function helps managers achieve coordination across the organization in the transformation of inputs into outputs." (Johnson and Davey, 2019, p. 42).

Self-evaluation concerning the present:

\begin{tabular}{lllll}
\hline-2 (worsening) & -1 & 0 & +1 & +2 (amelioration) \\
\hline Self-evaluation concerning the past: & & & \\
\hline-2 (worsening) & -1 & 0 & +1 & +2 (amelioration)
\end{tabular}

How has planning changed over the past year? What relevant actions and changes have taken place in this direction? Answer by giving specific examples (up to 100 words):

\section{M2. Job design (organization chart)}

"Job design refers to how the tasks, duties and responsibilities are performed and combined to make up the job" (Shaw et al., 2018, p. 288).

Self-evaluation concerning the present:

\begin{tabular}{lllll}
\hline-2 (worsening) & -1 & 0 & +1 & +2 (amelioration)
\end{tabular}

Self-evaluation concerning the past:

\begin{tabular}{lllll}
\hline-2 (worsening) & -1 & 0 & +1 & +2 (amelioration)
\end{tabular}

How has the job design changed over the past year? What relevant actions and changes have taken place in this direction? Answer by giving specific examples (up to 100 words):

\section{M3. Organizing}

"To organize means to create a workable structure and prepare for the design team's activities. It means taking responsibility for the orderly progression of the work required" (Stone, 2010, p. 30). 
Self-evaluation concerning the present:

-2 (worsening) $\quad-1$

Self-evaluation concerning the past:

\begin{tabular}{lllll}
\hline-2 (worsening) & -1 & 0 & +1 & +2 (amelioration)
\end{tabular}

How has organizing changed over the past year? What relevant actions and changes have taken place in this direction? Answer by giving specific examples (up to 100 words):

\section{M4. Staffing}

"Staffing refers to the extent to which companies consider person-environment fit to ensure congruence of individual and organizational values and goals that will facilitate knowledge sharing among employees when conducting recruitment and selection procedures" (Doan et al., 2011, p. 310).

Self-evaluation concerning the present:

\begin{tabular}{lllll}
\hline-2 (worsening) & -1 & 0 & +1 & +2 (amelioration)
\end{tabular}

Self-evaluation concerning the past:

\begin{tabular}{lllll}
\hline-2 (worsening) & -1 & 0 & +1 & +2 (amelioration)
\end{tabular}

How has staffing changed over the past year? What relevant actions and changes have taken place in this direction? Answer by giving specific examples (up to 100 words):

\section{M5. Leading}

"Leading refers to guiding improvement activities and establishing an organization's purpose, which changes over time" (Fliedner, 2011, p. 13).

Self-evaluation concerning the present:

\begin{tabular}{lllll}
\hline-2 (worsening) & -1 & 0 & +1 & +2 (amelioration)
\end{tabular}

Self-evaluation concerning the past:

\begin{tabular}{lllll}
\hline-2 (worsening) & -1 & 0 & +1 & +2 (amelioration)
\end{tabular}

How has leading changed over the past year? What relevant actions and changes have taken place in this direction? Answer by giving specific examples (up to 100 words):

\section{M6. Motivating}

"Motivating means enhancing the inner drives and positive intentions of subordinates (or others) to perform well through incentives, disincentives, and inspiration" (Wart, 2014, p. 469).

Self-evaluation concerning the present:

\begin{tabular}{lllll}
\hline-2 (worsening) & -1 & 0 & +1 & +2 (amelioration) \\
\hline Self-evaluation concerning the past: & & & +2 (amelioration) \\
\hline-2 (worsening) & -1 & 0 & +1 & +1 \\
\hline
\end{tabular}

How has motivating changed over the past year? What relevant actions and changes have taken place in this direction? Answer by giving specific examples (up to 100 words):

\section{M7. Control}

"Control is the process of ensuring that action conform to plans. In other words, control as a management function, means that once a course of action has been decided, operational decisions and activities of management should coincide with the plans" (Khan and Jain, 2013, p. 18.3).

Self-evaluation concerning the present:

\begin{tabular}{lllll}
\hline-2 (worsening) & -1 & 0 & +1 & +2 (amelioration) \\
\hline
\end{tabular}


Self-evaluation concerning the past:

\begin{tabular}{lllll}
\hline-2 (worsening) & -1 & 0 & +1 & +2 (amelioration)
\end{tabular}

How has control changed over the past year? What relevant actions and changes have taken place in this direction? Answer by giving specific examples (up to 100 words):

\section{M8. Coordinating (communication)}

"Coordinating refers to the ease with which interactions between members are conducted" (Respício et al., 2010, p. 67).

Self-evaluation concerning the present:

\begin{tabular}{lllll}
\hline-2 (worsening) & -1 & 0 & +1 & +2 (amelioration) \\
\hline Self-evaluation concerning the past: & & & +2 (amelioration) \\
\hline-2 (worsening) & -1 & 0 & +1 & +1
\end{tabular}

How has coordinating changed over the past year? What relevant actions and changes have taken place in this direction? Answer by giving specific examples (up to 100 words):

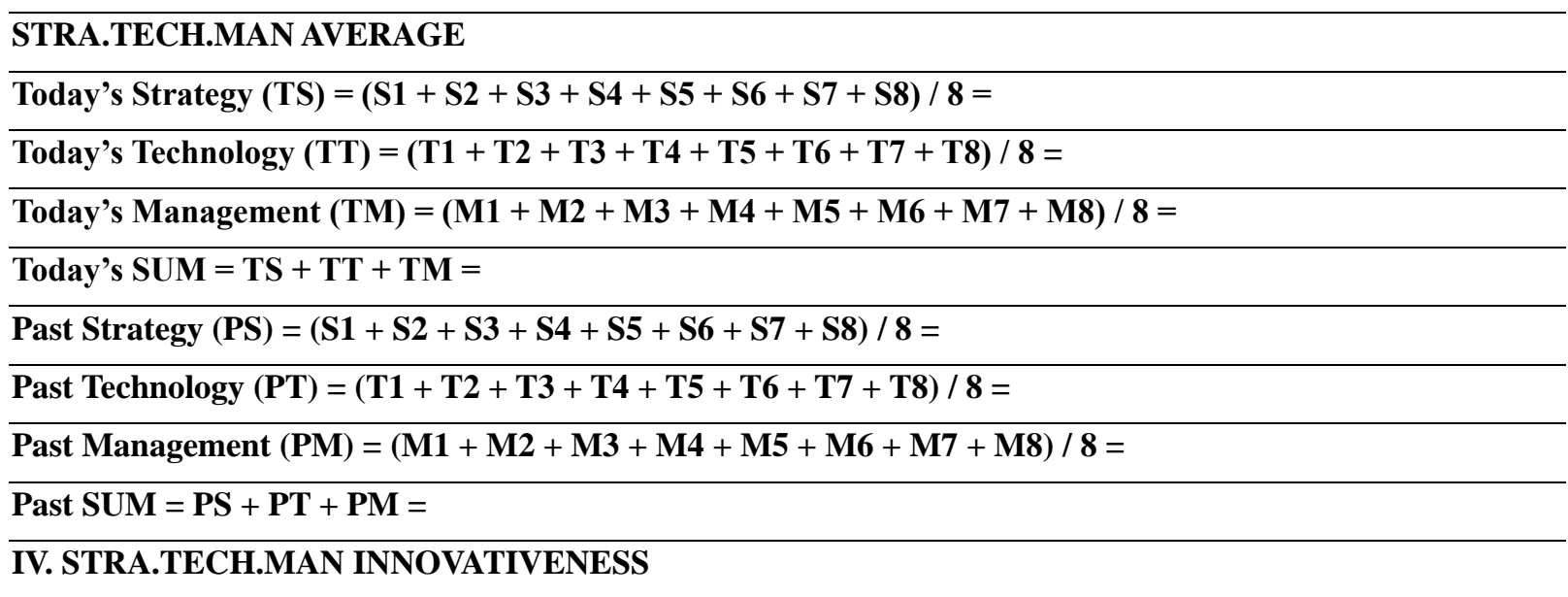

\section{STM1. Stra.Tech.Man comprehensiveness}

"Comprehensiveness means that all possible factors of the phenomenon (project) are addressed" (Umeda et al., 2015, p. 494).

Self-evaluation concerning the present:

\begin{tabular}{lllll}
\hline-2 (worsening) & -1 & 0 & +1 & +2 (amelioration) \\
\hline Self-evaluation concerning the past: & & & \\
\hline-2 (worsening) & -1 & 0 & +1 & +2 (amelioration)
\end{tabular}

How has "Stra.Tech.Man comprehensiveness" changed over the past year? What relevant actions and changes have taken place in this direction? Answer by giving specific examples (up to 100 words):

\section{STM2. Stra.Tech.Man consistency}

"Consistency refers to the degree of normative integration where leaders and followers have common mindset and high degree of conformity. It is an indicator of stability and internal integration" (Abdullah et al., 2014, p. 142).

Self-evaluation concerning the present:

\begin{tabular}{lllll}
\hline-2 (worsening) & -1 & 0 & +1 & +2 (amelioration) \\
\hline Self-evaluation concerning the past: & & & +2 (amelioration) \\
\hline-2 (worsening) & -1 & 0 & +1 & +1 \\
\hline
\end{tabular}


How has "Stra.Tech.Man consistency" changed over the past year? What relevant actions and changes have taken place in this direction? Answer by giving specific examples (up to 100 words):

\section{STM3. Stra.Tech.Man conciseness}

"The principle of conciseness refers to the fact that information needs to be sufficiently precise and detailed, so stakeholders can assess the performance of the organization" (García-Sánchez et al., 2019, p. 361).

Self-evaluation concerning the present:

\begin{tabular}{lllll}
\hline-2 (worsening) & -1 & 0 & +1 & +2 (amelioration)
\end{tabular}

Self-evaluation concerning the past:

\begin{tabular}{lllll}
\hline-2 (worsening) & -1 & 0 & +1 & +2 (amelioration)
\end{tabular}

How has "Stra.Tech.Man conciseness" changed over the past year? What relevant actions and changes have taken place in this direction? Answer by giving specific examples (up to 100 words):

\section{STM4. Stra.Tech.Man feasibility}

"The organizational virtue of feasibility refers to how employees feel enabled to fulfil their responsibilities through the provision of time, budgets, equipment, information, etc" (Kenny et al., 2019, p. 84).

Self-evaluation concerning the present:

\begin{tabular}{lllll}
\hline-2 (worsening) & -1 & 0 & +1 & +2 (amelioration) \\
\hline Self-evaluation concerning the past: & & & +2 (amelioration) \\
\hline-2 (worsening) & -1 & 0 & +1 & +1
\end{tabular}

How has "Stra.Tech.Man feasibility" changed over the past year? What relevant actions and changes have taken place in this direction? Answer by giving specific examples (up to 100 words):

\section{STM5. Stra.Tech.Man resilience}

"Organizational resilience refers to a business's ability to adapt and evolve as the global market is evolving, to respond to short-term shocks ... and to shape itself to respond to long-term challenges" (Bell, 2020, p. 41).

Self-evaluation concerning the present:

\begin{tabular}{lllll}
\hline-2 (worsening) & -1 & 0 & +1 & +2 (amelioration)
\end{tabular}

Self-evaluation concerning the past:

\begin{tabular}{lllll}
\hline-2 (worsening) & -1 & 0 & +1 & +2 (amelioration)
\end{tabular}

How has "Stra.Tech.Man resilience" changed over the past year? What relevant actions and changes have taken place in this direction? Answer by giving specific examples (up to 100 words):

\section{STM6. Stra.Tech.Man flexibility}

"Organizational flexibility refers to the ability of an organization to respond to a variety of changes in the competitive environment in an effective and timely manner" (Nandakumar et al., 2014, p. 1).

Self-evaluation concerning the present:

\begin{tabular}{lcccc}
\hline-2 (worsening) & -1 & 0 & +1 & +2 (amelioration) \\
\hline Self-evaluation concerning the past: & & & \\
\hline-2 (worsening) & -1 & 0 & +1 & +2 (amelioration)
\end{tabular}

How has "Stra.Tech.Man flexibility" changed over the past year? What relevant actions and changes have taken place in this direction? Answer by giving specific examples (up to 100 words):

\section{STM7. Stra.Tech.Man fidelity}

"Fidelity refers to the degree to which the intended design of the innovation is maintained during implementation" 
(Conrad and Poole, 2012, p. 359).

Self-evaluation concerning the present:

\begin{tabular}{lllll}
\hline-2 (worsening) & -1 & 0 & +1 & +2 (amelioration)
\end{tabular}

Self-evaluation concerning the past:

\begin{tabular}{lllll}
\hline-2 (worsening) & -1 & 0 & +1 & +2 (amelioration)
\end{tabular}

How has "Stra.Tech.Man fidelity" changed over the past year? What relevant actions and changes have taken place in this direction? Answer by giving specific examples (up to 100 words):

\section{STM8. Pace of Stra.Tech.Man change}

"The pace and direction of organizational change can be seen as driven by both internal and external factors, e.g. internal relationships can generate apparent resistance at the same time that evolutionary and revolutionary external changes occur" (Allen et al., 2011, p. 324).

Self-evaluation concerning the present:

\begin{tabular}{lllll}
\hline-2 (worsening) & -1 & 0 & +1 & +2 (amelioration) \\
\hline Self-evaluation concerning the past: & & & \\
\hline-2 (worsening) & -1 & 0 & +1 & +2 (amelioration)
\end{tabular}

How has the "pace of Stra.Tech.Man change" changed over the past year? What relevant actions and changes have taken place in this direction? Answer by giving specific examples (up to 100 words):

\section{STRA.TECH.MAN INNOVATIVENESS AVERAGE}

Today's Stra.Tech.Man Innovativeness (TSI) = (TSI1 + TSI2 + TSI3 + TSI4 + TSI5 + TSI6 + TSI7 + TSI8) / $\mathbf{8}=$

Past Stra.Tech.Man Innovativeness (PSI) = (PSI1 + PSI2 + PSI3 + PSI4 + PSI5 + PSI6 + PSI7 + PSI8) / 8 =

\section{FINANCIAL INDICATORS}

\section{Assets turnover $=$ sales revenue $/$ total assets}

Self-evaluation concerning the present:

\begin{tabular}{lllll}
\hline-2 (worsening) & -1 & 0 & +1 & +2 (amelioration)
\end{tabular}

Self-evaluation concerning the past:

\begin{tabular}{lllll}
\hline-2 (worsening) & -1 & 0 & +1 & +2 (amelioration)
\end{tabular}

Inventory turnover $=$ sales / inventory

Self-evaluation concerning the present:

\begin{tabular}{lllll}
\hline-2 (worsening) & -1 & 0 & +1 & +2 (amelioration) \\
\hline Self-evaluation concerning the past: & & & +2 (amelioration)
\end{tabular}

\section{Receivables turnover $=$ sales revenue $/$ average accounts receivable}

Self-evaluation concerning the present:

\begin{tabular}{lllll}
\hline-2 (worsening) & -1 & 0 & +1 & +2 (amelioration) \\
\hline Self-evaluation concerning the past: & & & +2 (amelioration) \\
\hline-2 (worsening) & -1 & 0 & +1 & +1
\end{tabular}




\section{Current ratio $=$ current assets $/$ current liabilities}

Self-evaluation concerning the present:

\begin{tabular}{lllll}
\hline-2 (worsening) & -1 & 0 & +1 & +2 (amelioration)
\end{tabular}

Self-evaluation concerning the past:

\begin{tabular}{lllll}
\hline-2 (worsening) & -1 & 0 & +1 & +2 (amelioration)
\end{tabular}

Debt ratio (leverage) $=$ total debts $/$ total assets

Self-evaluation concerning the present:

-2 (worsening) -1

$0+$

Self-evaluation concerning the past:

\begin{tabular}{lllll}
\hline-2 (worsening) & -1 & 0 & +1 & +2 (amelioration)
\end{tabular}

\section{Net profit margin $=$ net income $/$ sales revenue}

Self-evaluation concerning the present:

\begin{tabular}{lllll}
\hline-2 (worsening) & -1 & 0 & +1 & +2 (amelioration)
\end{tabular}

Self-evaluation concerning the past:

\begin{tabular}{lllll}
\hline-2 (worsening) & -1 & 0 & +1 & +2 (amelioration)
\end{tabular}

\section{Return on equity $(\mathrm{ROE})=$ net income / average shareholders' equity}

Self-evaluation concerning the present:

\begin{tabular}{lllll}
\hline-2 (worsening) & -1 & 0 & +1 & +2 (amelioration) \\
\hline Self-evaluation concerning the past: & & & +2 (amelioration) \\
\hline-2 (worsening) & -1 & 0 & +1 & +1
\end{tabular}

\section{Return of assets $($ ROA $)=$ net income / average total assets}

Self-evaluation concerning the present:

\begin{tabular}{lllll}
\hline-2 (worsening) & -1 & 0 & +1 & +2 (amelioration) \\
\hline Self-evaluation concerning the past: & & & +2 (amelioration) \\
\hline-2 (worsening) & -1 & 0 & +1 & +1 \\
\hline
\end{tabular}

\section{CONCLUDING QUESTION - To be discussed with your colleagues}

Can you name the highest potential weaknesses and strengths? (up to 500 words):

\section{Appendix B}

\section{The Stra.Tech.Man Scorecard in Charts (An Example)}

Figures B1 to B5 illustrate a Stra.Tech.Man scorecard's quantitative information. The numbers in this example are random. 


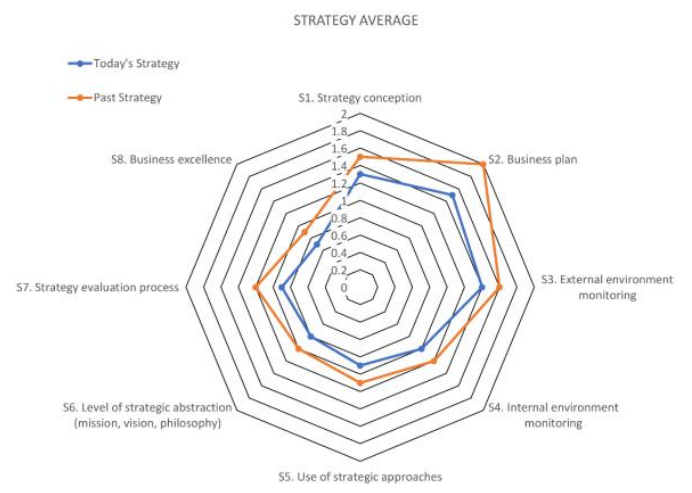

Figure B1. Today's and past strategy

Source: From grade zero to grade two. An example.

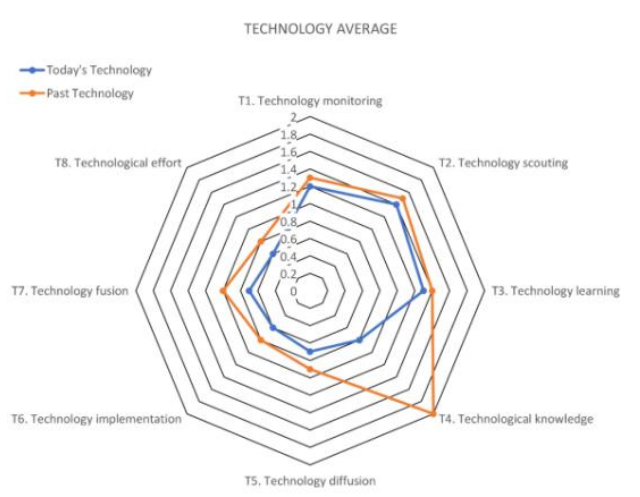

Figure B2. Today's and past technology

Source: From grade zero to grade two. An example.

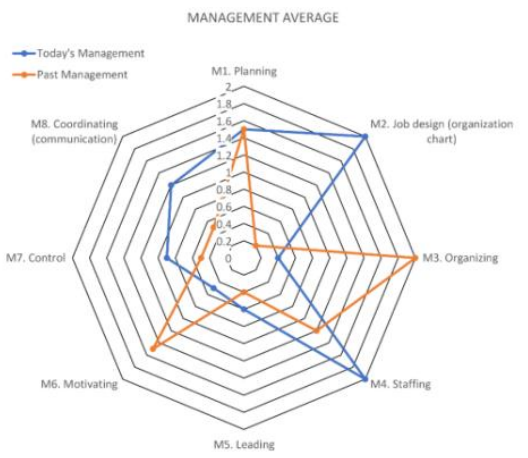

Figure B3. Today's and past management

Source: From grade zero to grade two. An example. 


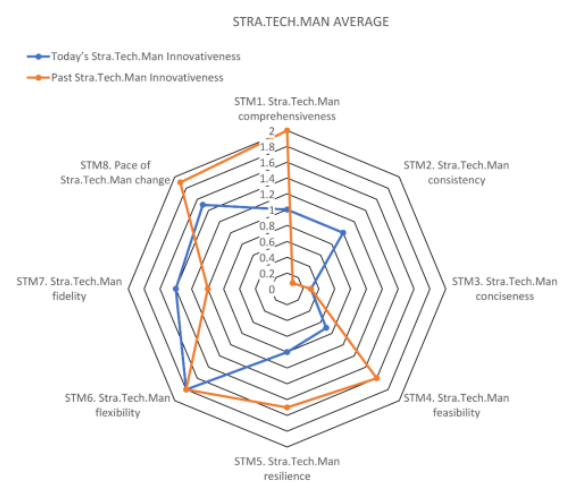

Figure B4. Today's and past Stra.Tech.Man average evaluation

Source: From grade zero to grade two. An example.

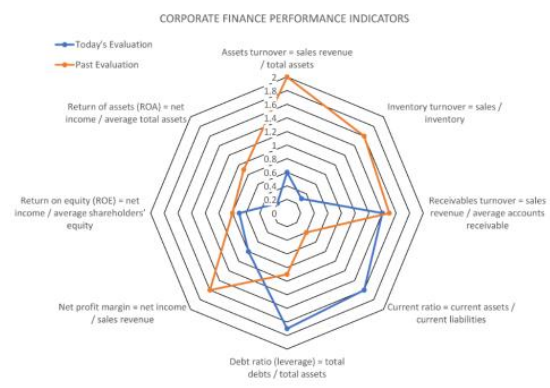

Figure B5. Today's and past corporate finance performance indicators evaluation

Source: From grade zero to grade two. An example.

\section{Copyrights}

Copyright for this article is retained by the author(s), with first publication rights granted to the journal.

This is an open-access article distributed under the terms and conditions of the Creative Commons Attribution license (http://creativecommons.org/licenses/by/4.0/). 